\title{
Benchmark Ratio Analysis Using One's Own College: An Experiential Learning Project for the Governmental and Not-For-Profit Accounting Course
}

\author{
Mary Michel \\ Manhattan College \\ O'Malley School of Business \\ mary.michel@manhattan.edu
}

August 3, 2020

Preliminary-Please do not cite or circulate. As I have been hospitalized recently, I do not have been able to edit as carefully as I would like.

I am grateful Dennis Lonergan, Controller of Manhattan College, for his insights into higher education accounting and the strategic financial analysis ratios and for comments from participants in the Effective Learning Strategies Poster Session at the American Accounting Association 2019 Annual Meeting. 


\title{
Benchmark Ratio Analysis Using One's Own College: A Service- Learning Project for the Governmental and Not-For-Profit Accounting Course
}

\begin{abstract}
Students calculate and analyze strategic financial statement ratios referenced by the National Association of College and University Business Officers (NACUBO) for this service learning project for the Governmental and Not-for-Profit Accounting course. After the instructor demonstrates the ratio calculation for the students' own college or university, students calculate ratios for peer, competitive and local institutions. Students found this topic interesting as current "customers" of and potential donors to their own college or university. Many auditors calculate some of these ratios for client institutions as a supplement to the audit report while referring to general benchmark ratios for all institutions. If the college or university's Controller or Chief Financial Officer wants to compare its institutional ratios to those of competing, local and peer institutions, students provide this analysis as service learning. The project provides an opportunity for students to deepen their understanding of to deepen students' understanding of the CPA examination topic of college and university reporting while honing analytical, judgement and critical thinking skills.
\end{abstract}

Keywords: Strategic financial analysis; higher education financial ratios

\section{INTRODUCTION}

Most Governmental and Not-for-Profit Accounting courses covers a great deal of technical accounting topics to prepare students to take the CPA examination. The author feels it equally important that students learn to find and review detailed information in recent governmental and not-for-profit financial statements and to analyze them with ratios. As a faculty observer for the Board of Trustees Finance committee, the author discovered the strategic financial analysis ratios prepared by the auditor and referenced by the National Association of College and University Business Officers (NACUBO). If the college or university's Controller of Chief Financial Officer wants to compare its institutional ratios to those of competing, local and peer institutions, students provide this analysis as service learning. Students found this topic interesting as current "customers" of and potential donors to their own college or university. The project provides an 
opportunity for students to deepen their understanding of the CPA examination topic of college and university reporting while honing analytical, judgement and critical thinking skills. The paper first describes the background for this exercise, then a detailed description with a list of requirements. A later section lists learning objectives for the project and implementation guidance. The paper concludes suggestions for future considerations.

\section{BACKGROUND}

The National Association of College and Business University Officers (NACUBO), credit analysts and the U.S. Department of Education have advocated the use of financial ratios analysis derived from a higher education institution's audited financial statements. On its website, the National Association of College and University Business Officers (NACUBO) contains a link to purchase the current edition of Strategic Financial Analysis for Higher Education, currently published by KPMG, Prager, Sealy \& Company and Attain (Tahey, P., Salluzzo, R., Prager, F., Mezzina, L., \& Cowen, C., 2010, 2016). These financial statement ratios were developed to track the time series of an institution's (a) liquidity and related risks, (b) strategic debt management, (c) operating risks and (d) capital risks. The current update to the Seventh edition considers the effects of the financial crisis on these ratios (Tahey, P., Salluzzo, R., Prager, F., Mezzina, L., \& Cowen, C., 2016). The ratios apply to both private and public higher education institutions, although the calculations may be slightly different for public institutions. Many auditors calculate a time series of at least some of these ratios for audit clients to present to the college or university's audit committee. 
Credit analysts calculate ratios identical or similar to these strategic financial ratios to rate the debt of colleges and universities. S\&P Global Ratings publish U.S. Not-For-Profit Private Universities Fiscal Median Ratios annually (Standard \& Poor's Financial Services, LLC, 2017). For example, S\&P Global Ratings ratio, Expendable resources (ER) to Operations, tracks the NACUBO referenced Primary Reserve Ratio. Credit analysts consider a combination of such ratios to assign credit ratings.

The Federal Student Aid website of the U.S. Department of Education describes its Financial Responsibility Score index, derived from the audited financial statements of higher education institutions. It is a composite of three ratios: a primary reserve ratio, an equity ratio and a net income rate, ranging in scale from negative one to positive three (most financially responsible) In its 2017-2018 spreadsheet, about thirty percent of its private and for-profit institutions (973 of 3,504) received a perfect score of 3.0. Thus, the ratio does not appear to distinguish levels of financial responsibility among the most highly rated institutions. (U.S. Department of Education, 2020)

Accounting research has examined at the effect of financial reporting choice on inputs to strategic financial ratios. Burgstahler and Sawers (2017) find incentives related to stakeholder groups are significant determinants of the net appreciation of endowment reporting choices for private colleges and universities. Accounting choice for the change in unrestricted net assets affect the net operating revenues ratio. 
The calculation and analysis of the strategic financial analysis ratios referenced by NACUBO give students the chance to develop many AICPA competencies, which are discussed in a future section. The project permits students to consider similar uses of ratios by credit analysts. The professor may help the students consider how accounting choices affect the calculation of such ratio, a consideration of college and university controllers. In addition, students must use judgement to choose the appropriate ratio inputs given the diverse presentation of information in the footnotes, particularly after the adoption of Accounting Standards Update No. 2016-14, Not for Profit Entities (Topic 958): Presentation of Financial Statements for Not-for-Profit Entities.

\section{CASE DESCRIPTION}

As a student close to graduation, you are a current "customer" of an institution of higher education. After graduation, your nonprofit or public institution hopes you will become an "investor" by donating financial resources. As an accounting student, you have learned to apply financial statement analysis to for-profit firms. This project helps you become aware of the strategic financial analysis ratios for such institutions, using judgement to find the appropriate items in financial statements to calculate them. You will answer questions in a discussion forum comparing the strategic financial analysis ratios of your assigned benchmark institution to those of your own institution and critically analyzing why ratios differ. If there is time, you and your classmates may collaborate on a presentation of benchmark strategic financial analysis for the controller or other interested authorities at your institution.

\section{LEARNING OBJECTIVES}

The learning objectives for the Government and Not-for-Profit Benchmark Ratio Analysis project are for students 
1. To understand the strategic information content of financial statements of higher education institutions through the use of strategic financial analysis ratios referenced by the National Association of College and Business University Officers (NACUBO) (Bloom's Taxonomy: Understand)

a. the Primary Reserve Ratio, measuring resources sufficiency and flexibility to support strategic goals.

b. the Viability Ratio, measuring strategic management of debt resources to advance strategic goals.

c. The Secondary Reserve Ratio, measuring the significance of permanently restricted net assets relative to operating size.

d. the Return on Net Assets Ratio, measuring total economic return.

e. the Net Operating Revenue Ratio, measuring how the surplus from operating activities affects the behavior of the other core ratios (Primary Reserve Viability and Return on Net Assets Ratios).

f. the Net Tuition Dependency Ratio referenced by NACUBO, measuring the sensitivity of revenue sources to enrollment patterns.

2. To use judgement to select the appropriate information from the financial statements of the assigned benchmark institution to correctly calculate these ratios. (Blooms Taxonomy-Apply). This has become more difficult after the adoption of ASU 2016-14, Presentation of Financial Statements of Not-for-Profit Entities, which became effective for fiscal years ending after December15, 2017.

3. To think critically by answering questions about the assigned benchmark institutions relative to others in a discussion forum. (Blooms Taxonomy: Analyze and Evaluate). 
4. Time permitting, to prepare a presentation integrating and analyzing calculations from assigned competitor higher education institutions to those of their own institution. (Blooms Taxonomy: Create).

The project addresses AICPA Core Competencies, including accounting competencies (measurement analysis and interpretation, research), business competencies (strategic perspective, industry/sector perspective) and professional competencies (collaboration and communication. Exhibit 1 discusses in further detail the mapping of AICPA Core Competencies for this project.

\section{DETAILED DESCRIPTION OF PROJECT}

The Benchmark Ratio Analysis Project needs to be implemented efficiently in a graduate Governmental and Not-for-Profit Accounting course that has a very full syllabus. I make the process of the project easier, so students can get the benefit of applying the strategic financial ratio for peer and competitive higher education institutions without an excess of time invested. Other instructors may wish to have students do these steps given time.

\section{Suggested Steps for Instructor before Project.}

1. Obtain a list of the competitive peer higher education institutions to compare to the student's own institution. I did so by asking my college's controller; alternatively, one may look through the institution's strategic plan. The controller provided a list of institutions that our institution uses to benchmark undergraduate tuition and fee analysis. The list includes private institutions like our college, but some public ones. The strategic financial analysis ratios referenced by the National Association of College and 
University Business Officers (NACUBO) apply to both types of institutions. Authors from KPMG, Prager, Sealy \& Co. and Attain have revised these references over time to reflect new financial disclosures and the financial crisis. (Tahey et al, 2010 and 2016, with link to purchase on from the NACUBO website).

2. Ask the controller for a copy of the audited financial statements with additional materials presented to the institution's Audit Committee. I was fortunate to have a controller interested in this project and its outcomes. My institution's auditor, KPMG, calculates six National Association of College and University Business Officers (NACUBO) strategic financial analysis ratios in a separate tab. These ratios are benchmarked for the institution over time, with general comments suggesting healthy levels for three of them.

3. Download the audited financial statements of a peer, competitive higher education institutions. Some years this task is easier than others. For 2016 and 2017, these were available at http://www.govwiki.info/pdfs/Non-Profit/. I did notice, however, that this list was not updated for most 2018 financial statements as of July 2019. If the audited financial statements are not available in a central location, one may use a general search or search each college's website. ProPublica's nonprofit explorer (https://projects.propublica.org/nonprofits/) has audited financial statements although they are not always timely. If the college borrows using municipal securities, timely audited financial statements may be available in the EMMA database of the Municipal Securities Regulatory Board (https://emma.msrb.org/Home/Index) or the or the DAC Bond website (https://www.dacbond.com/application?origin=main.jsp\&namespace=InvestorMain\&wf event=gosearch. 
4. Prepare a pre-formatted spreadsheet (see Exhibit 2a) with instructions for the student(s) to fill in the select figures from the assigned institution's financial statements in specific cells. I will share my template for this spreadsheet if you email me. My spreadsheet is formatted as follows:

a. Rows 1-6 of the Ratio spreadsheet contain instructions for it. Alternatively, these may be moved to another sheet in the same workbook.

b. Rows 8-9 assign respectively student names to analyze the statements of competitive higher education institutions for a specific year.

c. Each student will enter financial statement information for his or assigned higher education institution beginning in Row 23, in the 18 cells highlighted in pink (in rows $23-29,34,38,39,44,45,47,53,57,61,66$ and 70.)

d. After the students enter the data in the pink cells, subtotals for the need to calculation ratios appear in green, in rows 22, 40 and 40.

e. After entering data, the formulas I entered in rows 13, 16, 19, 22, 25 and 28 will calculate the six strategic financial analysis for your institution. To understand the ratio's meaning, see excerpt of the Ratio Analysis KPMG prepared for Manhattan College in Moodle with this assignment.

\section{Tasks for Students and Instructor during Project.}

1. Students complete the pre-formatted spreadsheet using the audited financial statements of the assigned benchmark institution, using judgement to find appropriate components of Expendable Net Assets, especially post adoption of ASU 2016-14.

2. Students upload the completed spreadsheet for the professor to correct. 
3. Professor corrects student submissions as necessary, then shares the combined corrected results in one spreadsheet (See Exhibit 2b)

4. Students answer questions to analyze the strategic financial analysis ratios of their assigned benchmark institution relative to other institutions in a discussion forum. These four questions, along guidance for grading them are described in detail in Exhibit 2.

5. Given sufficient time and number of students, prepare a slide deck with benchmark strategic financial ratios for the students' college and peer, competing institutions. This slide deck may be shared with the institution's controller or other authorities. At my institution, the controller entered this information into the Board of Trustees' Finance and Audit Committee records. Unfortunately, given limitations of time and number of students, I had to prepare this slide deck with the help of a graduate student aide. Exhibit 4 shows an example of the slide comparing the Primary Reserve Ratio for Manhattan College and Benchmark Institutions for the fiscal years ended in 2019.

\section{STUDENT FEEDBACK}

Exhibit 5 shows student feedback about the college strategic financial analysis benchmark ratio project. There were only eight students in the class, which was smaller than prior years.

Overall, students ranked the project highly, answering the rated questions with scores between 4.13 and 4.88 out of 5. Students strongly felt that finding and reading detailed information from the audited financial statements of assigned benchmark institutions reinforced their understanding of not-for-profit reporting (4.77 out of 5). I was surprised that they did not find responding to the discussion questions as helpful as scouring the financial statements (4.13 out of 5). Students strongly agreed that having the project at the end of the course was helpful, reinforcing what they learned about not-for-profit accounting at the beginning of the course (4.88 
out of 5). The seven students who added written comments were uniformly positive about the project.

\section{FUTURE CONSIDERATIONS}

As stated in the detailed description steps, there is much more opportunity for students to demonstrate judgement, creativity and critical thinking in this project. Larger classes make it possible to assign more analytical and design tasks to groups of students. For example:

- Students may work on the slide deck presentation, adding commentary about the ratios.

- Students may calculate and analyze the ratios for their assigned competitor institutions across time. This time series of ratios for my student's college is already available in the audit report.

- Students may supplement the strategic financial analysis ratings recommended by NACUBO with metrics used by credit rating agencies. Each year, S\&P Global Ratings publishes a document describing U.S. Not-for-Profit Private Universities Median Ratios. This permits students to look at ratings for all private higher education institutions, rather than those of competitor schools.

- Ratios may be added for competing public colleges and universities. The design of strategic financial ratios referenced by NACUBO accommodates both types of private and public institutions. Students may compare reporting differences for public institutions using GASB standards to those of private institutions using FASB standards.

- Students may design their own ratios or try new ones that I created. For the Net Tuition Dependence Ratio can be distorted by allocations of costs among educational and auxiliary expenses. A way to avoid this is to create a Net Tuition and Auxiliary Revenue 
Dependence ratios that uses educational, general and auxiliary expenses as a denominator.

In December of 2019, the AICPA published Maintaining the Relevance of the Uniform CPA Examination®: An Exposure Draft and Invitation to Comment. This document proposed removing many governmental accounting topics. If this occurs, there would be more time in many Governmental and Not-for Profit Accounting courses to implement the strategic financial analysis project more fully, with more learning objectives demonstrating analysis, evaluation and creation. 
Exhibit 1: Mapping of AICPA Core Competencies and Case Requirements

\begin{tabular}{|l|l|}
\hline ACCOUNTING COMPETENCIES \\
\hline $\begin{array}{l}\text { Measurement, Analysis and } \\
\text { Interpretation }\end{array}$ & $\begin{array}{l}\text { Compute \& analyze the strategic financial ratios used } \\
\text { by NACUBO for colleges and universities. }\end{array}$ \\
\hline Research & $\begin{array}{l}\text { Consult references for preparers of strategic financial } \\
\text { analysis recommended by NACUBO to use judgement } \\
\text { in computation and analysis }\end{array}$ \\
\hline BUSINESS COMPETENCIES & $\begin{array}{l}\text { Understand strategic financial risks and indicative } \\
\text { financial ratios for higher education institutions. }\end{array}$ \\
\hline Strategic Perspective & $\begin{array}{l}\text { Understand strategic financial ratios for both public and } \\
\text { private higher education institutions. }\end{array}$ \\
\hline Industry/Sector Perspective & $\begin{array}{l}\text { Potential group work when computing and analyzing } \\
\text { ratios }\end{array}$ \\
\hline PROFESSIONAL COMPETENCIES \\
\hline Collaboration & $\begin{array}{l}\text { Prepare a presentation to benchmark these ratios across } \\
\text { pompetitive higher education institutions (time }\end{array}$ \\
\hline Communication & \\
\hline
\end{tabular}




\section{Exhibit 2A: Spreadsheet Inputs for College Strategic Ratio Benchmark Analysis}

\begin{tabular}{|c|c|c|c|}
\hline & STUDENT & Faculty & Student \\
\hline & INSTITUTION ASSIGNED & Manhattan College & XYZ College \\
\hline & YEAR & FYE 06/30/2019 & FYE 06/30/19 \\
\hline & IAL STATEMENT ITEMS & & \\
\hline FROM BALANCE SHEET & & & \\
\hline Expendable Net Assets= & & $97,449,948$ & - \\
\hline Unrestricted Net & & $147,494,249$ & \\
\hline Temporarily Res & Net Assets & $70,373,745$ & \\
\hline Net Assets with & nents available for general purposes (Notes) & $1,991,582$ & \\
\hline less Property, $\mathrm{Pl}$ & quipment, net & $(200,199,175)$ & \\
\hline less Capital Proje & RNA hin 2017, 2016 only per KPMG & $(6,658,767)$ & \\
\hline plus Long-Term & nancial Statements) & $97,658,611$ & \\
\hline plus unamortize & bt Issue Costs & $1,472,067$ & \\
\hline less Funds held $k$ & Trustee & $(14,682,364)$ & \\
\hline Expendable Net Assets- & atio & $97,450,000$ & \\
\hline Difference & & $(52)$ & \\
\hline Permanently Restricted & sets (PRNA) per Financial Statements & $66,473,336$ & \\
\hline PRNA rounded in KPMG & & $66,473,000$ & \\
\hline Difference-frounding & & 336 & \\
\hline Long Term Debt-Financi & ment & $97,658,611$ & \\
\hline add back unamortized is & sts in 2017, 2016, 2015 only (presentation chan & $1,472,067$ & \\
\hline Adjusted LT Debt for KP & ios in 2017, 2016 \& 2105 & $99,130,678$ & \\
\hline Long-Term Debt for KPN & o-rounded & $99,131,000$ & \\
\hline Difference-rounding & & $(322)$ & \\
\hline Total Net Assets-Beginn & & $275,177,719$ & \\
\hline Unrestricted Net Assets & ing & $147,271,619$ & \\
\hline FROM STATEMENT OF A & & & \\
\hline Total Unrestricted Reve & & $140,486,485$ & \\
\hline plus Net Assets Release & Restrictions related to capital projects, in 2017 & & \\
\hline & & $140,486,485$ & \\
\hline Total Unrestricted Reve & unded for KPMG Ratios & $140,486,000$ & \\
\hline Difference Rounding & & 485 & \\
\hline Net Tuition Revenue in & al Statements & $88,363,056$ & \\
\hline Net Tuition Revenue rou & or KPMG Ratios & & \\
\hline Difference rounding & & & \\
\hline Total Expenses FS & & $142,834,957$ & \\
\hline Total Expenses rounded & MG & $142,835,000$ & \\
\hline difference due to round & & (43) & \\
\hline Auxiliary Expenses & & $20,948,595$ & \\
\hline Total Education \& Gene & enses $=$ Total Expenses - Auxiliary Expenses & $121,886,405$ & \\
\hline Total E \& G KPMG round & & & \\
\hline Difference-rounding & & & \\
\hline Change in Unrestricted I & ets & 222,630 & \\
\hline Change in URNA KPMG & & 223,000 & \\
\hline Difference rounding & & $(370)$ & \\
\hline Change in Net Assets & & $11,155,193$ & \\
\hline Change in Net Assets KP & io rounded & $11,155,000$ & \\
\hline Difference Rounding & & 193 & \\
\hline
\end{tabular}


Exhibit 2B: Spreadsheet Strategic Financial Ratios Calculated from Inputs

\begin{tabular}{|c|c|c|c|c|}
\hline & STUDENT & Faculty & Student YR & Student AD \\
\hline & INSTITUTION ASSIGNED & Manhattan College & Iona College & Fordham University \\
\hline & YEAR & FYE 06/30/2019 & FYE 06/30/19 & FYE 06/30/19 \\
\hline \multicolumn{5}{|c|}{ RATIO CALCULATION } \\
\hline $\begin{array}{l}\text { Primary Reserve Ratio = } \\
\text { (measures financial strength: } K M P G \\
\text { advises a ratio of } .40 \text { to } 1 \text { or better) }\end{array}$ & Expendable Net Assets/Total Expenses & 0.68 & 1.29 & 0.62 \\
\hline $\begin{array}{l}\text { Viability Ratio= (determines } \\
\text { financial health, the most creditworthy } \\
\text { institutions have ratios over } 1.25 \text { ) }\end{array}$ & Expendable Net Assets/Long-Term Debt & 0.98 & 1.70 & 0.94 \\
\hline $\begin{array}{l}\text { Secondary Reserve Ratio= } \\
\text { (measures significance of permanently } \\
\text { restricted net assets relative to operating } \\
\text { size) }\end{array}$ & Permanently Restricted Net Asset/Total Expenses & 0.47 & 0.26 & 0.60 \\
\hline $\begin{array}{l}\text { Return on Net Assets= } \text { (represents } \\
\text { the college's total economic return, KPMG } \\
\text { recommends 3-5\%) }\end{array}$ & Change in Net Assets/Total Net Assets-beginning & $4.1 \%$ & $5.6 \%$ & $3.9 \%$ \\
\hline $\begin{array}{l}\text { Net Tuition Dependency Ratio= } \\
\text { (the extent to which tuition finances } \\
\text { expenses. It is institution specific) }\end{array}$ & Net Tuition Revenue/Total Educational \& General Expenses & $72.5 \%$ & $85.2 \%$ & $\mathrm{~N} / \mathrm{A}$ \\
\hline $\begin{array}{l}\text { Net Operating Revenues Ratio= } \\
\text { (a primary indicator of } \\
\text { operating surplus and } \\
\text { strength) }\end{array}$ & Change in Unrestricted Net Assets /Total Unrestricted Revenue & $0.2 \%$ & $12.8 \%$ & $2.4 \%$ \\
\hline
\end{tabular}




\section{EXHIBIT 3}

\section{Guideline for Grading Discussion Board Questions}

\begin{tabular}{|c|c|}
\hline Question: & Guidelines for Grading \\
\hline $\begin{array}{l}\text { 1. Discuss why the Primary Reserve Ratio for your assigned } \\
\text { institution may differ from that of Benchmark College ( } 25 \\
\text { points). (Primary Reserve Ratio = Expendable Net Assets/Total } \\
\text { Expenses). In doing so, look at the items in the calculation of } \\
\text { Expendable Net Assets, the numerator of the Primary Reserve } \\
\text { Ratio. Look at how the proportion of items in Expendable Net } \\
\text { Assets for your company might differ from those of Manhattan } \\
\text { College. }\end{array}$ & $\begin{array}{l}\text { Higher points were given for: } \\
\text { - Showing calculations of the } \\
\text { proportions of items in Expendable } \\
\text { Net Assets relative to those at } \\
\text { Manhattan College } \\
\text { - Questioning whether expenses } \\
\text { were unusually high or low in the } \\
\text { focus year } \\
\text { - Taking into account information } \\
\text { from the institution's media about } \\
\text { buildings, gifts and other } \\
\text { transactions. }\end{array}$ \\
\hline $\begin{array}{l}\text { 2. Discuss three differences between format or content of the } \\
\text { Statement of Financial Position and Statement of Activities for } \\
\text { your assigned college/university and those of Manhattan } \\
\text { College in } 2019 \text { ( } 25 \text { points). For example, in } 2019 \text { Manhattan } \\
\text { College discloses Net assets without Restrictions and Net Assets } \\
\text { with Restrictions on its Statement of Financial Position as } \\
\text { required by Accounting Standards Update 2016-14. Before this } \\
\text { there were three categories, Unrestricted Net Assets, Temporarily } \\
\text { Restricted Net Assets and Permanently Restricted Net Assets. } \\
\text { Some colleges give more details in the Net Assets with Restrictions } \\
\text { section of the Balance Sheet about net assets with time and } \\
\text { purpose restrictions (formerly known as temporarily restricted net } \\
\text { assets). }\end{array}$ & $\begin{array}{l}\text { This question was graded for the } \\
\text { correctness of distinctions made between } \\
\text { the student's assigned institution and the } \\
\text { benchmark. I wanted students to make one } \\
\text { another aware of the differences in } \\
\text { language, format and details of the financial } \\
\text { statements among these benchmark } \\
\text { institutions. The differences in the format } \\
\text { of the Statement of Financial Position } \\
\text { increased after adoption of ASU 2016-14, } \\
\text { for fiscal years beginning after December } \\
15,2017 \text {. }\end{array}$ \\
\hline $\begin{array}{l}\text { 3. Discuss three differences in disclosure in the Notes of the } \\
\text { audited financial statements of your assigned } \\
\text { college/university and Manhattan College in } 2019 \text { ( } 25 \text { points). }\end{array}$ & $\begin{array}{l}\text { This question was graded for the } \\
\text { correctness of distinctions made in the level } \\
\text { of disclosure between the student's assigned } \\
\text { institution and the benchmark. }\end{array}$ \\
\hline $\begin{array}{l}\text { 4. Discuss how you expect the COVID pandemic to affect the } \\
\text { Primary Reserve Ratio for your college/university in } \\
2020 \text {. For example, most colleges and universities are } \\
\text { expecting a reduction in net assets due to (a) losses on } \\
\text { Investment Assets and (b) refunds of revenue from room and } \\
\text { board. (25 points) }\end{array}$ & $\begin{array}{l}\text { Higher points were given for: } \\
\text { Noticing that some expenses might } \\
\text { be reduced concurrent with } \\
\text { revenues, particularly expenses } \\
\text { related to room and board. } \\
\text { - Noticing that additional expenses } \\
\text { and capital related to online } \\
\text { learning were necessary } \\
\text { - Giving consideration to } \\
\text { composition of the Investment } \\
\text { Asset portfolio in considering } \\
\text { changes in investment value. } \\
\text { Giving consideration to } \\
\text { governmental aid or philanthropy } \\
\text { to offset losses. }\end{array}$ \\
\hline
\end{tabular}


Exhibit 4: Slide for Benchamarking thePrimary Reserve Ratio in 2019

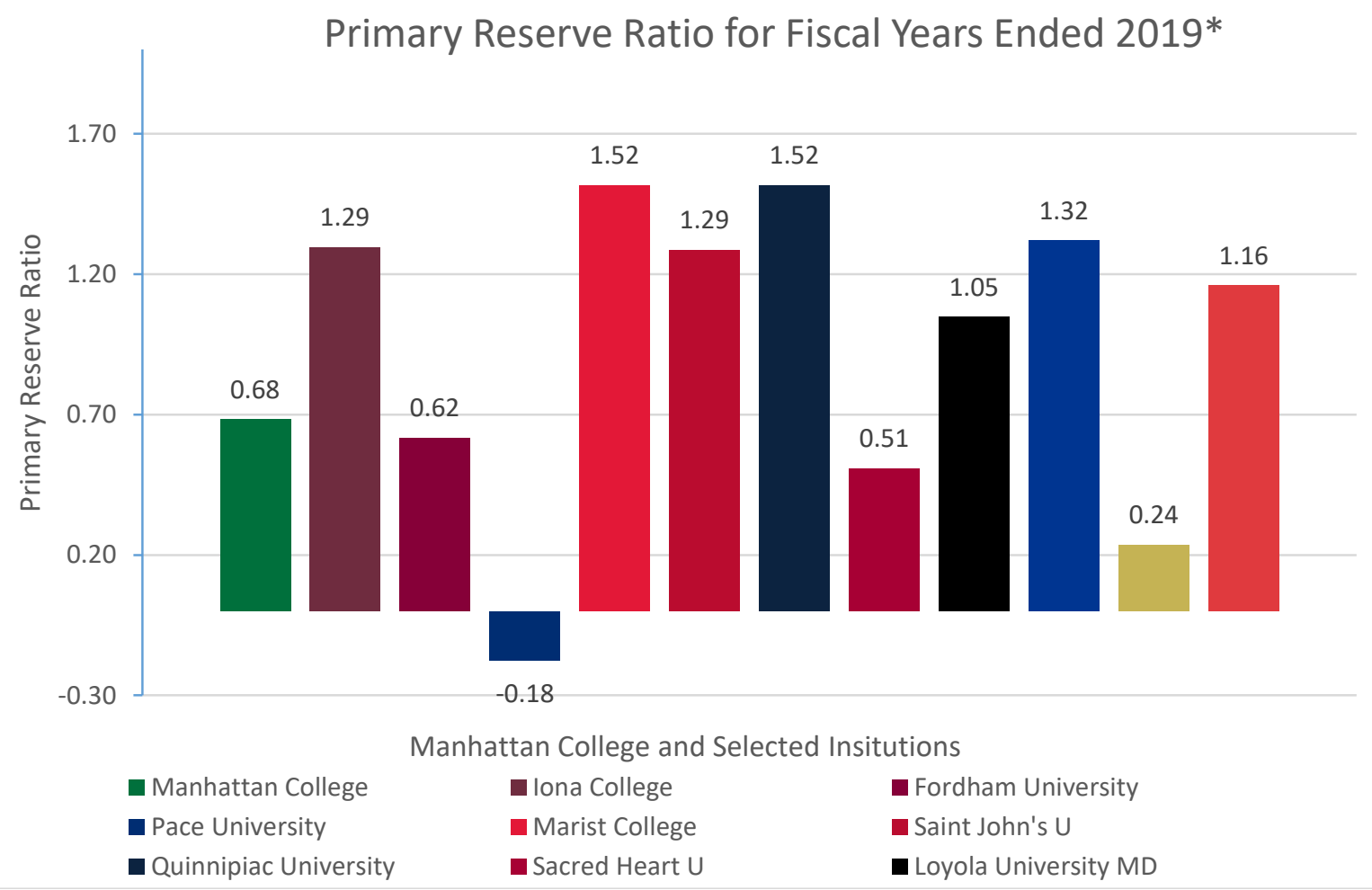




\section{Exhibit 5: Summary of Student Feedback}

\begin{tabular}{|c|c|c|c|}
\hline \multirow[t]{2}{*}{$\begin{array}{l}\text { Survey } \\
\text { Question } \\
\text { Number }\end{array}$} & \multirow[t]{2}{*}{ Question Text } & \multicolumn{2}{|c|}{$\begin{array}{l}\text { Spring } 2020 \\
\text { Graduate } \\
\text { Governmental and } \\
\text { Nonprofit } \\
\text { Accounting Class } \\
(\mathrm{n}=8) \\
\end{array}$} \\
\hline & & Mean & $\begin{array}{l}\text { Standard } \\
\text { Deviation }\end{array}$ \\
\hline 1 & $\begin{array}{l}\text { The slide deck and/or its associated video, Project } \\
\text { Instructions: Strategic Financial Analysis Ratio for } \\
\text { Manhattan College and Select Benchmark Institutions, } \\
\text { helped me to understand the purpose of the College } \\
\text { Strategic Financial Analysis project. }\end{array}$ & 4.50 & 0.53 \\
\hline 2 & $\begin{array}{l}\text { Finding and reading detailed information from the audited } \\
\text { financial statements and footnotes of my assigned college } \\
\text { or university helped reinforce my understanding of not- } \\
\text { for-profit reporting. }\end{array}$ & 4.75 & 0.46 \\
\hline 3 & $\begin{array}{l}\text { Replying to the Discussion Questions for the College } \\
\text { Strategic Financial Analysis Ratio project helped me to } \\
\text { think critically about financial reporting for not-for-profit } \\
\text { colleges and universities. }\end{array}$ & 4.13 & 0.83 \\
\hline 4 & $\begin{array}{l}\text { Having the College Strategic Financial Analysis Project at } \\
\text { the end of the course was helpful to me, rather than at the } \\
\text { beginning of the course when not-for-profit accounting } \\
\text { topics were covered. }\end{array}$ & 4.88 & 0.35 \\
\hline 5 & $\begin{array}{l}\text { Please feel free to add your comments or suggestions } \\
\text { about the College Strategic Financial Analysis Ratio } \\
\text { Project. }\end{array}$ & \multicolumn{2}{|c|}{$\begin{array}{l}\text { Seven students } \\
\text { provided uniformly } \\
\text { positive written } \\
\text { comments. }\end{array}$} \\
\hline
\end{tabular}

Questions 1-4 responses are based on a five-point scale where 1 equals "Strongly disagree" and 5 equals "Strongly agree". Eight students of ten enrolled in the class replied to questions 1 through 4. Seven of ten enrolled students provided open-ended written feedback to question 5 


\section{References}

Burgstahler, D.C. and Sawyers, K.M. 2017. Mangagement of Financial Performance Measures: Evidence from Private Colleges and Universities. Journal of Governmental \& Nonprofit Accounting. 6 (1): 1-29. doi: 10.2308/ogna-51849

Butler, M.G., Church, K.S. and Wheeler Spencer, A. 2019. Do, reflect, think, apply: Experiential education in accounting. Journal of Accounting Education. Governmental \& Nonprofit Accounting. 48: 12-21. https:/doi.org/10.1016/j.jaccedu.2019.05.001

Financial Accounting Standards Board (FASB). 2016. Presentation of Financial Statements of Not-For-Profit Entities.FASB Accounting Standards Update: Not-For-Profit Entities (Topic 958). Available at: https://fasb.org/cs/ContentServer?c=Document_C\&cid=1176168381847\&d=\&pagename =FASB\%2FDocument_C\%2FDocumentPage

Standard \& Poor's Financial Services LLC. (2017). U.S. Not-For-Profit Private Universities Fiscal 2016 Median Ratios: A Stable Sector Despite Uncertainties. Available at https://www.spratings.com/documents/20184/1057001/U.S.+Not+For+Profit+Private+U niversities+Fiscal+2016+Median+Ratios/7f089b0d-7ac2-47e5-b3eb-1a491f52acf8

Standard \& Poor's Financial Services LLC. (2019). U.S. Not-For-Profit Private Universities Fiscal 2016 Median Ratios: Overall Stability Continues Despite Lingering Issues. Available at https://www.spglobal.com/ratings/en/research/articles/190625-u-s-not-forprofit-private-universities-fiscal-2018-median-ratios-overall-stability-continues-despitelingering-11038485

Tahey, P., Salluzzo, R., Prager, F., Mezzina, L., \& Cowen, C. (2010). Strategic Financial Analysis for Higher Education. 7th edition, New York, NY: KPMG, Prager, Sealy, \& Co., LLC, and Attain. (Available at http://products.nacubo.org/index.php/strategicfinancial-analysis-for-higher-ed-7th-ed.html)

Tahey, P., Salluzzo, R., Prager, F., Mezzina, L., \& Cowen, C. (2016). Update to the 7th edition of strategic financial analysis for higher education. USA: KPMG, Prager, Sealy, \& Co., LLC, and Attain. (Available at http://products.nacubo.org/index.php/leadership/updateto-the-7th-edition-of-strategic-financial-analysis-in-higher-education.html)

U.S. Department of Education (2020). Financial Responsibility Composite Scores. Available at https://studentaid.gov/data-center/school/composite-scores (last accessed July 7, 2020). 